\title{
Persorption Mechanisms of Luminal Antigenic Particulates via Apoptotic Epithelial Cells of Intestinal Villi into Systemic Blood Circulation in Orally Immunized Rats
}

\author{
Midori YUJI ${ }^{1)}$, Masato FUJIMOTO'), Hidenori MIYATA ${ }^{2)}$, Tetsurou INAMOTO'), \\ ${\text { Wang-Mei } \mathrm{QI}^{1)} \text {, Kenkichi YAMAMOTO }}^{1)}$, Katsuhiko WARITA ${ }^{1)}$, Toshifumi YOKOYAMA ${ }^{3)}$, Nobuhiko HOSHI ${ }^{1)}$ and \\ Hiroshi KITAGAWA ${ }^{1) *}$
}

${ }^{1)}$ Departments of Bioresource and Agrobiosciences and ${ }^{2}$ Animal Science, Graduate School of Science and Technology, Kobe University, Kobe 657-8501 and ${ }^{3}$ Department of Anatomy and Neurobiology, Faculty of Medicine, Kagawa University, Kagawa 761-0793, Japan

(Received 12 October 2006/Accepted 24 November 2006)

ABSTRACT. The possibility of persorption of prefixed bovine serum albumin-coated sheep erythrocytes (BSA-SEs) from mucous epithelial cells and its mechanisms were investigated in rats orally immunized by BSA for 14 consecutive days. On the day after the final oral immunization, the rats were duodenally perfused by BSA-SEs or non-coated SEs. BSA-SEs were also duodenally perfused in nonimmunized rats. Thirty min after perfusion, BSA-SEs were significantly more engulfed by late-apoptotic-stage villous columnar epithelial cells in the orally immunized rats than those in other experiments. The specific antibody (SpAb) was detected on the surfaces of BSA-SEs in rats with oral immunization. In Peyer's patches of all animals, no SEs reached the follicle-associated epithelium, because of the close attachment of follicle-associated intestinal villi and the thick mucous layer. BSA-SEs were more frequently persorbed into portal blood in the orally immunized rats than in other rats. Small numbers of BSA-SEs or SEs were detected in the systemic blood of all animals. BSA-SEs were also histologically found in the blood vessels of the liver, but not in mesenteric lymph nodes. These findings suggest that sensitized antigenic particulates are taken up by late-apoptotic-stage villous columnar epithelial cells in the small intestine and are finally persorbed into the systemic blood circulation. The uptake of antigenic particulates might be mediated by its luminal $\mathrm{SpAb}$. KEY WORDS: apoptosis, particule, persorption, small intestine, specific antibody.

J. Vet. Med. Sci. 69(4): 339-346, 2007

The mucous epithelium of the intestine is constantly exposed to an enormous number of ingested macromolecules in foods, resident bacteria, invading microorganisms, and so on [34]. In general, the intestinal barrier is permeable to low-molecular-weight nutrients, such as amino acids, small peptides, monosaccharides, fatty acids and glycerol, but impermeable to macromolecules, particular antigens and most microorganisms [25]. Information on luminal antigens and microorganisms is generally taken up by special epithelial cells, M cells, exclusively located in the follicle-associated epithelium of mucosal lymphatic tissues [25].

On the other hand, since orally ingested starch particles were found in both the peripheral blood and urine of a dog in 1844 [15], many investigators have reported the phenomenon, persorption, by which macromolecules [27, $31,45]$ or particulates $[6,17,42]$ are transported from the intestinal lumen to peripheral blood circulation. The orally ingested particulates that have been reported in peripheral blood and urine, range in size up to $150 \mu \mathrm{m}$ in diameter [For more details, see the review of Volkheimer, 40, 41]. Persorbed particulates have been found in various tissues, such as blood, bile, urine, lymph nodes, spleen, lung, kidney and brain $[16,44]$. Persorption is observed in a wide range of animal species including both fishes and mammals [27, 42]. In spite of numerous reports on persorption, however, it is not described in textbooks and its mechanisms have not

\footnotetext{
* Correspondence to: Kitagawa, H., Graduate School of Science and Technology, Kobe University, Kobe 657-8501, Japan.
}

yet been clarified.

In neonatal animals, intact luminal macromolecules, such as IgG [1], lactoferrin (LF) [14] and EGF [12], can penetrate the epithelial barrier of the small intestine and be persorbed into the peripheral blood. The persorption of macromolecules such as LF and IgG in animal intestines ceases after gut closure [7, 28, 29], however, it has been reported that LF is persorbed from the intestinal lumen into the blood circulation $[13,24,38]$, and that food antigens and their immune complexes are also persorbed from the intestine into the peripheral blood in adult humans $[8,18]$. In a previous study, we suggested that luminal bovine serum albumin (BSA) antigen is persorbed by villous columnar epithelial cells at the late apoptotic stage, being mediated by the specific antibody $(\mathrm{SpAb})$ in orally immunized juvenile rats. Therefore, in the present study, we clarify the persorption mechanism of antigenic particulates from the intestinal lumen to demonstrate the persorption of particulates in juvenile rats.

\section{MATERIALS AND METHODS}

Animals: A total of 15 male Wistar rats aged 5 weeks (Japan SLC, Japan) were maintained under conventional laboratory housing conditions. The animals were treated according to the guidelines for the care and use of experimental animals at Rokkodai Campus of Kobe University. They were permitted free access to water and food (Lab MR Stock; Nosan Corp., Japan) containing no bovine-derived proteins. The animal facility was 
maintained under conventional conditions with a 12-hr light/dark cycle at $21 \pm 1{ }^{\circ} \mathrm{C}$ and $50-60 \%$ humidity. Clinical and pathological examinations confirmed that none of the animals showed any sign of a disorder.

Experimental protocol: Rats were divided into the following three groups. Five rats were orally administered 0.75\% BSA (Fraction V; Serologicals Proteins, U.S.A.) solution $(1 \mathrm{~m} l)$ for 14 consecutive days and were injected with BSA-coated sheep erythrocytes (BSA-SEs) into the duodena (Group BB). Another five rats were administered BSA solution for 14 consecutive days and were injected with non-coated SEs into the duodena (Group BC). The rest of five were administered no BSA solution for 14 consecutive days and were injected with BSA-SEs into the duodena (Group CB).

Preparation of non-coated SEs: Sheep blood (Nippon Biotest Lab., Japan) was centrifuged at $400 \mathrm{~g}$ for $10 \mathrm{~min}$, and the supernatant was removed. The sedimented SE fraction from which the buffy coat had been removed was immersion-fixed with $2.5 \%$ glutaraldehyde in $0.1 \mathrm{M}$ phosphate buffer (PB, pH 7.4) for $1 \mathrm{hr}$ at r.t. The rinsed SEs were colorized by a peroxidase reaction using a 3,3'diaminobenzidine (Dojindo Lab., Japan) solution containing $0.03 \% \mathrm{H}_{2} \mathrm{O}_{2}$ (DAB). Colorized SEs were rinsed and suspended in RPMI-1640 (Nissui Pharmaceutical, Japan). The final concentration of SEs was adjusted to $4 \times 10^{6} / \mathrm{m} l$.

Preparation of BSA-SEs: Colorized SEs were refixed in $2.5 \%$ glutaraldehyde in $0.1 \mathrm{M} \mathrm{PB}(\mathrm{pH} \mathrm{7.4)}$ for $1 \mathrm{hr}$ at r.t. After rinsing in PB, SEs were incubated with a $1 \%$ BSA (Wako Pure Chemical Industries, Japan) solution for $1 \mathrm{hr}$ at r.t. The rinsed BSA-SEs were suspended in RPMI-1640. The final concentration of SEs was adjusted to $4 \times 10^{6} / \mathrm{m} l$.

Administration of SEs and BSA-SEs: Under anesthesia with peritoneal injection of pentobarbital sodium (Dainippon Sumitomo Pharma., Japan), $2 \mathrm{ml}$ of BSA-SEs or non-coated SEs suspended in solution were warmed up to $38^{\circ} \mathrm{C}$ and perfused into the duodenum by means of a plastic syringe equipped with a 22-gauge needle through a small abdominal incision. After the perfusion, the animals were settled in a warm and quiet chamber.

Tissue preparation: At $30 \mathrm{~min}$ after the perfusion, blood was collected from the portal vein and caudal vena cava under anesthesia. After cardiac puncture, small tissue blocks were obtained rapidly from the duodenum, jejunum including Peyer's patch, ileum, spleen, liver, mesenteric lymph node and kidney, followed by immersion-fixation in periodate-lysine-paraformaldehyde (PLP) and Bouin's fixatives for $24 \mathrm{hr}$ at $4{ }^{\circ} \mathrm{C}$. The tissue blocks were then dehydrated and embedded in paraffin by routine procedures and cut into $4-\mu \mathrm{m}$-thick sections. They were mounted onto 3-aminopropyltriethoxysilane (Shin-Etsu Chemical, Japan)coated glass slides. The PLP-fixed paraffin sections were stored at $4{ }^{\circ} \mathrm{C}$ until use. Bouin's fixed and deparaffinized sections were stained with hematoxylin and eosin (HE).

Detection of anti BSA antibody: After deparaffinization, endogenous peroxidase was eliminated by immersion in absolute methanol and in $0.5 \% \mathrm{H}_{2} \mathrm{O}_{2}$ for $30 \mathrm{~min}$ each, followed by incubation with $2 \%$ normal chicken serum for 1 $\mathrm{hr}$ at r.t. Thereafter, the sections were reacted with $0.01 \%$ dinitrophenyl-BSA (Molecular Probes, U.S.A.) for $1 \mathrm{hr}$ at r.t., and incubated with HRP-conjugated anti dinitrophenyl rabbit IgG (diluted at 1:50; Dako, Denmark) for $20 \mathrm{hr}$ at $4^{\circ} \mathrm{C}$. Finally, the sections were colorized with $\mathrm{DAB}$ and slightly counterstained with hematoxylin.

In situ nick-end labeling method: The bromodeoxyuridin triphosphate (BrdUTP) method was applied to detect the final features of the apoptotic villous columnar epithelial cells according to the method described by Yuji et al. [47]. Briefly, four sections were prepared (Sections 1, 2, 3, and 4). Sections 1 and 2 were used as positive controls for section 3. Section 4 was used as a negative control. After deparaffinization, the sections were pretreated with $6.0 \mu \mathrm{g} /$ $\mathrm{m} l$ proteinase $\mathrm{K}$ solution (Sigma-Aldrich, U.S.A.) for 15 min at $37^{\circ} \mathrm{C}$. After treatment with both absolute methanol and $0.5 \% \mathrm{H}_{2} \mathrm{O}_{2}$, sections 1 and 2 were incubated with 1.5 $\mathrm{mg} / \mathrm{m} \mathrm{l}$ DNase I solution (Boehringer Mannheim, Germany) for $10 \mathrm{~min}$ at $37^{\circ} \mathrm{C}$. Sections 1 and 3 were incubated with terminal deoxynucleotidyl transferase (TdT) buffer (Roche Diagnostics, Switzerland) containing BrdUTP solution (0.1 $\mathrm{nM}$ BrdUTP in $4 \mathrm{~m} l$ distilled water; Sigma-Aldrich) for $2 \mathrm{hr}$ at $37^{\circ} \mathrm{C}$. All sections were then incubated with $1 \%$ normal bovine serum for $1 \mathrm{hr}$ at r.t., and were treated with anti BrdUTP mouse monoclonal antibody (diluted at 1:20; Bioscience Products, Japan) for $18 \mathrm{hr}$ at $4^{\circ} \mathrm{C}$. The sections were then reacted with anti mouse IgG rat IgG (diluted at 1:50; Jackson ImmunoRes. Lab., U.S.A.) for $1 \mathrm{hr}$ at r.t., and treated with mouse PAP (diluted at 1:50; Seikagaku Corp., Japan) for $1 \mathrm{hr}$ at r.t. Finally, the sections were incubated with DAB and counterstained weakly with hematoxylin.

Absorption frequencies of SE by intestinal epithelial cells: The number of intraepithelial SEs was counted in 20 intestinal villi which were sectioned longitudinally, and were randomly selected in each duodenum. The engulfed SEs were carefully distinguished from SEs that overlaid or underlaid the section under a light microscope using a $100 \times$ objective lens. The mean number of each group was compared by Student's $t$ test. $P$ values less than 0.05 were considered statistically significant. Data were presented as mean number \pm standard deviation.

Portal vein and peripheral blood examination: Hematocrit and erythrocyte counts were examined by standard methods. SE numbers were counted in blood smear preparations of $5 \mu l$ of portal blood and systemic blood in each animal. Hematocrit, erythrocyte count and SE count among groups were analyzed by Student's $t$ test. $P$ values less than 0.05 were considered statistically significant. Data were presented as mean number \pm standard deviation.

Total number of persorbed SE: The number of SEs transported into systemic circulation from the intestinal lumen during the migration of SEs through the small intestine, was calculated by following formula:

[Number of SEs in $1 \mu l$ of systemic blood] $\times$ [Cardiac output $(\mu l / \mathrm{min})] \times[$ Transit time in small intestine $(\mathrm{min})]$. 
In the formula, the absorption rate of SEs from the small intestine was assumed to be constant during the migration through the small intestine, and all SEs in systemic circulation were assumed to be cleared from the systemic blood during 1 circulation. The transit time of chyme through the small intestine and the heart output rate were 88 min and $74 \mathrm{ml} / \mathrm{min}[4]$, respectively.

\section{RESULTS}

Absorption of SE in the intestinal epithelium: At $30 \mathrm{~min}$ after duodenal perfusion of SEs, they reached the distal jejunum. SEs were almost restricted to the central intestinal lumen, but few SEs diffused into the mucous of intervillous spaces. It was easy to distinguish SEs from rat erythrocytes, because SEs were slightly smaller than rat erythrocytes and were colorized brown by DAB.

In the apices of the intestinal villi, a number of SEs adhered to the striated borders of epithelial cells in all animals (Fig. 1). No elongated cytoplasmic process reached the SEs from the apical surfaces of the epithelial cells. In the epithelium, a few SEs were contained in both the supranuclear and infranuclear cytoplasms (Fig. 2). The SEcontaining epithelial cells were typical microvillous columnar epithelial cells, which were accompanied with no epithelial pockets harboring migrating cells. Most SEcontaining epithelial cells were characterized by cytoplasmic and heterochromatin condensation (Fig. 2). No SE was observed in the lamina propria under the epithelium or in either the blood capillaries or central lymphatics.
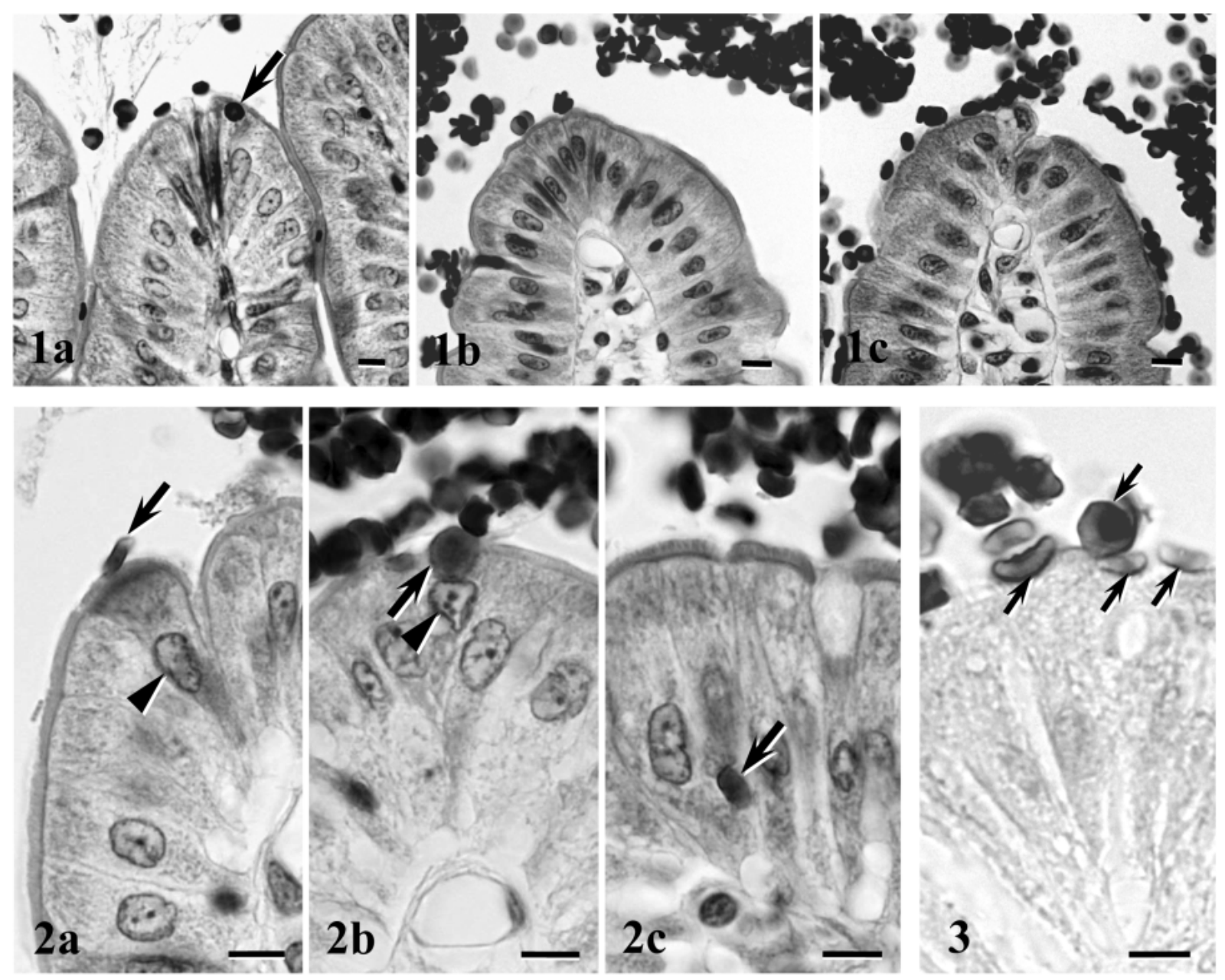

Fig. 1. Apical regions of intestinal villi in group BB (a). BSA-SE is engulfed by a villous columnar epithelial cell (arrow). No intraepithalial BSA-SE or SE is seen at the apical region of the intestinal villus in group BC (b) or CB (c). Diffused BSA-SEs or SEs are attached to the surfaces of the apical regions in all experimental groups. Bar $=10 \mu \mathrm{m}$.

Fig. 2. High magnification micrographs of absorption of BSA-SEs in group BB. a) BSA-SE (arrow) is adhered to the striated borders of a villous columnar epithelial cell, whose chromatin and cytoplasm are slightly condensed (arrowhead). b) BSA-SE (arrow) is engulfed by an apoptotic epithelial cell with typical morphological apoptotic features, such as chromatin condensation and luminal shift of nucleus (arrowhead). c) BSA-SE is transported through the cytoplasm (arrow). Bar $=10 \mu \mathrm{m}$.

Fig. 3. Strongly positive intensity of anti BSA antibody is visible on the surfaces of BSA-SEs attached to the striated border of a villous columnar epithelial cell in the villous apex (arrows) of group BB. Bar $=10 \mu \mathrm{m}$. 


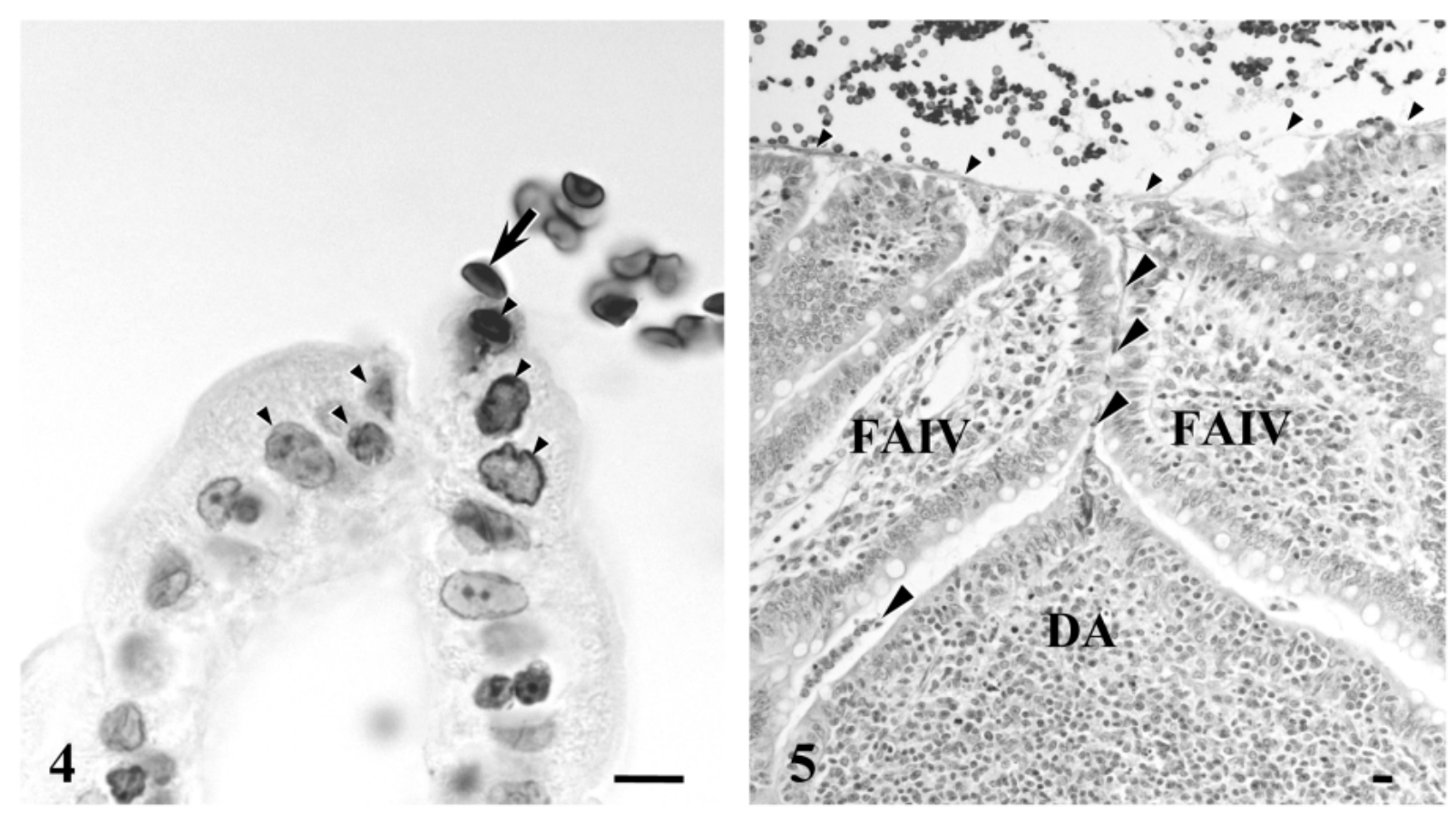

Fig. 4. Nuclear DNA fragmentation (arrowheads) is visible in the apex of an intestinal villus of group BB. BSA-SE (arrow) is attached the exfoliating epithelial cell with the strongest DNA fragmentation. Bar $=10 \mu \mathrm{m}$.

Fig. 5. A Peyer's patch FAE in group BB is covered by the adjacent follicle-associated intestinal villi (FAIV) except for a narrow pathway that is filled with mucous containing exfoliated cellular debris (large arrowheads). The mucous covers the entire mucous membrane (small arrowheads). No SE reached the FAE. DA, dome area. Bar $=10 \mu \mathrm{m}$.

Table 1. Quantitative results in experimental groups

\begin{tabular}{|c|c|c|c|c|c|c|c|c|}
\hline \multirow[b]{2}{*}{$\begin{array}{l}\text { Experimental } \\
\text { Group }\end{array}$} & \multirow{2}{*}{$\begin{array}{c}\text { Duodenum } \\
\text { Number of } \\
\text { Intraepithelial } \\
\text { SEs }^{1)}\end{array}$} & \multicolumn{3}{|c|}{ Portal blood } & \multicolumn{4}{|c|}{ Systemic blood } \\
\hline & & $\begin{array}{c}\text { Hematocrit } \\
(\%)\end{array}$ & $\begin{array}{l}\text { Total } \\
\text { erythrocyte } \\
\text { number }\end{array}$ & $\begin{array}{l}\text { Number of } \\
\text { persorbed } \\
\text { SEs }^{2)}\end{array}$ & $\begin{array}{c}\text { Hematcrit } \\
(\%)\end{array}$ & $\begin{array}{l}\text { Total } \\
\text { erythrocyte } \\
\text { number }\end{array}$ & $\begin{array}{l}\text { Number of } \\
\text { persorbed } \\
\text { SEs }^{3)}\end{array}$ & $\begin{array}{l}\text { Total } \\
\text { persorbed } \\
\text { SEs }^{4)}\end{array}$ \\
\hline $\mathrm{BB}$ & $11.0 \pm 1.8^{\mathrm{a})}$ & $42.1 \pm 0.0$ & $6.1 \pm 0.5$ & $3.3 \pm 2.5^{\mathrm{b})}$ & $39.8 \pm 2.8$ & $6.1 \pm 1.5$ & $1.5 \pm 1.9$ & $13.8 \times 10^{5}$ \\
\hline $\mathrm{BC}$ & $5.1 \pm 0.6$ & $45.9 \pm 2.3$ & $7.1 \pm 0.6$ & $1.4 \pm 1.5$ & $39.8 \pm 9.1$ & $5.9 \pm 1.7$ & $0.6 \pm 0.9$ & $5.5 \times 10^{5}$ \\
\hline $\mathrm{CB}$ & $3.1 \pm 2.7$ & $43.9 \pm 1.6$ & $6.0 \pm 1.2$ & $0.2 \pm 0.4^{\mathrm{b})}$ & $42.1 \pm 1.8$ & $6.1 \pm 1.9$ & $0.4 \pm 0.9$ & $3.7 \times 10^{5}$ \\
\hline
\end{tabular}

BB: Preliminary oral administration of BSA + BSA-coated sheep erythrocytes. BC: Preliminary oral administration of BSA + naked erythrocytes. CB: No oral administration of BSA + BSA-coated sheep erythrocytes. 1) Mean number \pm SD of intraepithelial SEs in 20 randomly selected intestinal villi. 2) Mean number \pm SD of persorbed SEs in $5 \mu l$ of portal blood. 3) Mean number \pm SD of persorbed SEs in $5 \mu l$ of systemic blood. 4) Estimation of the expected total number of persorbed sheep erythrocytes in systemic blood circulation during migration through the small intestine. a) differs from $\mathrm{BC}$ and $\mathrm{CB}(p<0.01)$. b) $p<0.05$ between b).

In immunohistochemistry, SpAb was detected in the luminal contents in groups BB and BC. SpAb was also detected in the cytoplasm of villous columnar epithelial cells at the apices of intestinal villi. In group BB, the surfaces of BSA-SEs were also positive against $\mathrm{SpAb}$ in the intestinal lumen (Fig. 3). The SE-attaching sites were restricted to the areas of the villous epithelium that came in contact with SE-containing chyme and where nuclear DNAfragmentation was also accelerated (Fig. 4).

The engulfment of SEs by villous columnar epithelial cells was frequently found in group BB, but hardly observed in groups BC and CB (Fig. 1). In histoplanimetry, the absorption frequency of SE was significantly greater in group BB than in groups BC and CB $(p<0.01)$ (Table 1).
In Peyer's patches, FAEs were covered by adjacent follicle-associated intestinal villi, except for the narrow tips of FAE. Moreover, the narrow spaces between FAE and follicle-associated intestinal villi were filled with mucous. No luminal SE reached the surface of FAE in any animal (Fig. 5).

Fate of SE after epithelial absorption: From histological observation, SEs were detected in some interlobular veins, central veins and sinusoidal capillaries, but no SE-laden stellate macrophages and hepatocytes were found in any animal (Fig. 6). SEs were detected in the interlobular veins of kidney in group $\mathrm{BB}$, while no SE was phagocytized by macrophages (Fig. 7). SEs were not observed in the spleen or mesenteric lymph nodes of any animal. 

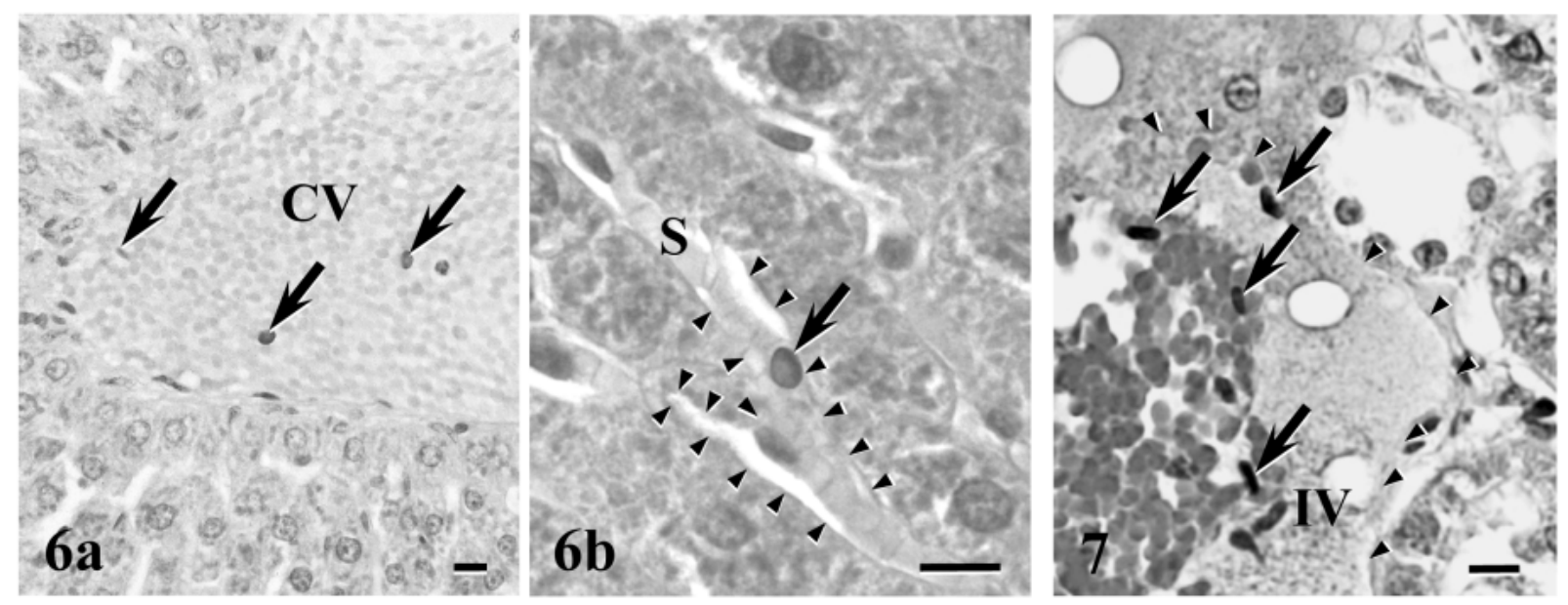

Fig. 6. In a liver of group BB, BSA-SEs (arrows) are contained in the central vein (CV) (a) and sinusoid (S) (b). The sinusoid is encircled with arrowheads. Bar $=10 \mu \mathrm{m}$

Fig. 7. In a kidney of group BB, BSA-SEs (arrows) are visible in the interlobular vein (IV). The lumen of the vein is encircled with arrowheads. $\mathrm{Bar}=10 \mu \mathrm{m}$.

From hematological observation, single SEs were detected in both portal blood and systemic blood in all experimental groups. No SEs were phagocytized by leucocytes. SEs were detected significantly more frequently in the portal blood of group BB than in those group CB. Hematocrit ratios and total erythrocyte counts were similar in all experimental groups (Table. 1).

From our calculations, in group BB the total number of SEs persorbed into systemic blood circulation during their migration through the small intestine was $13.8 \times 10^{5}$ (Table. 1). This number corresponded to $0.02 \%$ of the total number of administered SEs.

\section{DISCUSSION}

Persorption of orally ingested particulates, such as diatoms, pollens, spores, cellulose particulates, plant cells, starch granules, polyvinyl chloride particles or metal particulates, into systemic circulation from the intestinal lumen, has been reported in various mammalian animal species [40], but the transition mechanism of luminal particulates into intestinal tissue is still unclear. One possible transition route of such particulates into the tissue has been proposed: a route via the desquamated portions of the epithelium in intestinal villi $[39,43]$. During the exfoliation of apoptotic epithelial cells, however, the epithelial junctional complex between the neighboring epithelial cells in the apices of intestinal villi is ultrastructurally preserved [19, 36]. No epithelial desquamation is ultrastructurally found in the apices of intestinal villi or FAE of Peyer's patches of rats (unpublished data). According to our previous study, the BSA-antigen molecule and its SpAb are absorbed by apoptotic microvillous columnar epithelial cells at the apices of intestinal villi and FAEs of Peyer's patches in orally BSA-immunized rats. From these epithelial cells of the apices, the BSA-antigen molecule and its SpAb are transported to subepithelial tissue through an intracytoplasmic route that is composed of small vesicles [47]. In the present study, the SEs that were attached to the apical membrane of epithelial cells were engulfed by epithelial cells and transported through the epithelial cytoplasm to the subepithelial tissue. These findings suggest that the luminal sensitized antigenic molecules and particulates take an intracytoplasmic route.

Before gut closure, maternal IgG is endocytosed by the Fc receptor on the apical membranes of villous epithelial cells and is released into the subepithelial tissue in a $\mathrm{pH}$ dependent manner [32]. The mRNA of the neonatal IgGbinding receptor ( $\mathrm{FcRn}$ ) gradually decreases until adulthood in rats [11], while FcRn is still expressed on intestinal epithelial cells in adult humans and mediates the transportation of $\mathrm{IgG}$ [5]. Furthermore, in adult rats, $\mathrm{IgG}$ is absorbed by intestinal epithelial cells [46]. The food antigen and its immune complex are absorbed and transported into peripheral blood in adult humans [8, 18]. Our previous study suggests that the absorption and transcytosis of the luminal BSA-antigen are mediated by its $\mathrm{SpAb}$ in small intestines of orally BSA-immunized rats [47]. In the present study, BSA-SE absorption in orally BSA-immunized animals was significantly more frequent than in animals with no oral immunization or no BSA-coated SE administration. The SpAb was detected on the surfaces of BSA-coated SEs in the intestinal lumen of orally BSAimmunized animals. These results suggest that the absorption of luminal antigenic particulates is also mediated by its $\mathrm{SpAb}$.

In our previous study, the absorption of the luminal BSAantigenic molecule and its $\mathrm{SpAb}$ was restricted to the villous apices that contacted the BSA-containing chyme, and the apoptotic process was also accelerated in the epithelial cells in orally BSA-immunized rats. Moreover, the epithelial 
cells with more active absorption of the BSA-antigenic molecules were also accompanied by stronger nuclear DNA fragmentation in the orally immunized rats [47]. Our present study suggests that engulfment of antigenic particulates occurred in the apoptotic epithelial cells at the villous apices that contacted the BSA-SEs containing chyme. Therefore, these findings also suggest the close relationship between epithelial apoptosis and the absorption of both luminal antigenic particulates and SpAb. Creutzfeldt-Jakob disease is thought to be caused by the absorption of infected prions derived from contaminated beef. The infected prions may be taken up by either an Mcell-dependent or -independent route in the small intestine [10]. The apoptotic epithelial cell-dependent route found in the present study might be one of the infection routes under the condition of SpAb existing in the intestinal lumen.

$M$ cells in the FAE of mucosal lymphatic tissues generally absorb luminal antigens that induce intestinal immune responses [9]. However, almost all of the FAEs were covered with adjacent mucosa in human Peyer's patches and rabbit appendices $[26,30]$. In rat Peyer's patches, the FAE except for the narrow area of the apical region is covered with follicle-associated intestinal villi. The narrow space between the FAE and adjacent villi is filled with thick mucous [3]. These findings are also confirmed in our study. Moreover, M cells are predominantly distributed in the basal to middle regions rather than the apical regions of the FAEs in Peyer's patches of rats, rabbits, humans and mice [3, 22, 30,35], of rabbit cecal lymphoid patches [22], and of chicken cecal tonsils [23]. On the other hand, detailed histoplanimetrical study suggests that the appearance of $\mathrm{M}$ cells is closely correlated with bacterial colonization in the FAE of rat Peyer's patches [3]. The engulfment of bacteria by $\mathrm{M}$ cells in the rabbit appendix requires the bacteria to be able to access the FAE [26]. Moreover, both the BSA-antigen and its $\mathrm{SpAb}$ are absorbed by apoptotic apical epithelial cells in the apical FAE rather than by M cells in the basal FAE of Peyer's patches in orally BSA-immunized rats [47]. In the present study, no SEs reached the FAEs in any experimental groups because of prevention of diffusion of SEs by both the adjacent follicle-associated intestinal villi and mucous. This finding strongly supposes the hypothesis [3] that most M cells are away from the stream of luminal contents and that the situation of M cells in the FAE is unsuitable for constant monitoring of luminal food antigens under physiological conditions in animals.

Special antigen-trapping cells, intestinal villous $\mathrm{M}$ cells, have been found in the intestinal villi of mice [20]. Villous $\mathrm{M}$ cells accompanied by intraepithelial pockets were detected in the villous epithelium by lectin histochemistry by means of UEA-1, and take up some species of bacteria [20]. In our previous study of orally immunized rats, however, the antigenic molecule and its SpAb are absorbed by apoptotic microvillous columnar epithelial cells whose nuclear DNA is fragmented and which have no intraepithelial pockets [47]. The present study suggests that the epithelial cells which engulfed the SEs were restricted to the villous apices that came in contact with the antigenic particulate-containing chyme; the apoptotic process was also accelerated in these epithelial cells. Moreover, SEengulfing epithelial cells were accompanied by no intraepithelial pockets. Consequently, these findings further support our previous hypothesis [47] that the epithelial cells in rat intestinal villi which take up both the luminal antigen and its antibody are themselves apoptotic, unlike intestinal villous $\mathrm{M}$ cells.

Our previous study demonstrated that the absorbed BSAantigen and its $\mathrm{SpAb}$ are transported to both blood vessels and lymph vessels in the mucosa of orally BSA-immunized rats [47]. However, SEs were transported to systemic circulation exclusively via the portal vein; in the present study no SEs were detected in the lymph vessels or mesenteric lymph nodes. In clinical cases of multiple portosystemic shunts in dogs, bacteremia develops because the portal blood bypasses the liver to the systemic circulation [17]. These results might suggest that both macromolecules and particulates can enter blood vessels in the intestinal villi.

In the liver, stellate macrophages generally possess phagocytic ability on bacteria, viruses and aging erythrocytes $[2,33]$. On the other hand, egg lecithin-coated silicon particulates of $0.5-1.5 \mu \mathrm{m}$ in diameter in the portal blood are phagocytosed by hepatocytes more than by stellate macrophages in rats [37]. Smaller polystyrene particulates less than $1 \mu \mathrm{m}$ which are orally or per-enterally administrated, more numerously secrete into the bile in a size-dependent manner [21]. In the previous study, BSAantigenic molecule and its $\mathrm{SpAb}$ were also engulfed by hepatocytes more than by stellate macrophages, while no SEs were engulfed by hepatocytes or stellate macrophages in the present study. These results suggest that small immune complexes are engulfed by hepatocytes rather than stellate macrophages, but no large particular immune complexes might be able to reach the hepatocytes because of the impossibility of passing through the sinusoidal endothelium.

No phagocytosis of SEs could be found in any tissues we examined. To clarify the immunological significance of persorption, the clearance sites of persorbed particulates and phagocytotic mechanisms acting on them are very important. Further investigation will be necessary to explain the significance of intestinal persorption.

ACKNOWLEDGMENTS. This work was financially supported in part by Grants-in-Aid for Scientific Research (nos. 13660298 and 16580239) from the Japan Society for the Promotion of Science.

\section{REFERENCES}

1. Baintner, K. and Toth, I. 1986. Failure to demonstrate intestinal absorption of RNA in the newborn pig: preliminary communication. Acta Vet. Hung. 34: 239-241.

2. Banks, W. J. 1993. Applied veterinary histology, 3rd ed., 
Mosby-Year Book, U. S. A.

3. Chin, K., Onishi, S., Yuji, M., Inamoto, T., Qi, W.-M., Warita, K., Yokoyama, T., Hoshi, N. and Kitagawa, H. 2006. Differentiation of epithelial cells to $\mathrm{M}$ cells in response to bacterial colonization on the follicle-associated epithelium of Peyer's patch in rat small intestine. J. Vet. Med. Sci. 68: 10231028.

4. Davies, B. and Morris, T. 1993. Physiological parameters in laboratory animals and humans. Pharm. Res. 10: 1093-1095.

5. Dickinson, B. L., Badizadegan, K., Wu, Z., Ahouse, J. C., Zhu, X., Simister, N. E., Blumberg, R. S. and Lencer, W. I. 1999. Bidirectional FcRn-dependent IgG transport in a polarized human intestinal epithelial cell line. J. Clin. Invest. 104: 903911.

6. Florence, A. T., Hillery, A. M., Hussain, N. and Jani, P. U. 1995. Nanoparticles as carriers for oral peptide absorption: studies on particle uptake and fate. J. Control. Release 36: 3946.

7. Fransson, G. B., Thoren-Tolling, K., Jones, B., Hambraeus, L. and Lonnerdal, B. 1983. Absorption of lactoferrin in suckling pigs. Nutr. Res. 3: 373-384.

8. Gardner, M. L. G. 1988. Gastrointestinal absorption of intact proteins. Ann. Rev. Nutr. 8: 329-360.

9. Gebert, A., Rothkötter, H. J. and Pabst, R. 1996. M cells in Peyer's patches of the intestine. Int. Rev. Cytol. 167: 91-159.

10. Ghosh, S. 2002. Intestinal entry of prions. Z. Gastroenterol. 40: $37-39$.

11. Gill, R. K., Mahmood, S., Sodhi, C. P., Nagpaul, J. P. and Mahmood, A. 1999. IgG binding and expression of its receptor in rat intestine during postnatal development. Indian $J$. Biochem. Biophys. 36: 252-257.

12. Gonnella, P. A., Siminoski, K., Murphy, R. A. and Neutra, M. R. 1987. Transepithelial transport of epidermal growth factor by absorptive cells of suckling rat ileum. J. Clin. Invest. 80: $22-32$.

13. Harada, E., Itoh, Y., Sitizyo, K., Takeuchi, T., Araki, Y. and Kitagawa, H. 1999. Characteristic transport of lactoferrin from the intestinal lumen into the bile via the blood in piglets. Comp. Biochem. Physiol. A Mol. Integr. Physiol. 124: 321-327.

14. Harada, E., Sugiyama, A., Takeuchi, T., Sitizyo, K., Syuto, B., Yajima, T. and Kuwata, T. 1999. Characteristic transfer of colostral components into cerebrospinal fluid via serum in neonatal pigs. Biol. Neonate 76: 33-43.

15. Herbst, G. 1844. Das lymphgefäßsystem und seine verrichtung. Nach eigenen untersuchungen dargestellt, Verlag von Vandenhoek und Ruprecht, Göttingen.

16. Hillyer, J. F. and Albrecht, R. M. 2001. Gastrointestinal persorption and tissue distribution of differently sized colloidal gold nanoparticles. J. Pharm. Sci. 90: 1927-1936.

17. Howe, L. M., Boothe, D. M. and Boothe, H. W. 1999. Detection of portal and systemic bacteremia in dogs with severe induced hepatic disease and multiple portosystemic shunts. Am. J. Vet. Res. 60: 181-185.

18. Husby, S., Jensenius, J. C. and Svehag, S. E. 1986. Passage of undegraded dietary antigen into the blood of healthy adults. Further characterization of the kinetics of uptake and the size distribution of the antigen. Scand. J. Immunol. 24: 447-455.

19. Iwanaga, T., Han, H., Adachi, K. and Fujita, T. 1993. A novel mechanism for disposing of effete epithelial cells in the small intestine of Guinea pigs. Gastroenterology 105: 1089-1097.

20. Jang, M. H., Kweon, M. N., Iwatani, K., Yamamoto, M., Terahara, K., Sasakawa, C., Suzuki, T., Nochi, T., Yokota, Y., Rennert, P. D., Hiroi, T., Tamagawa, H., Iijima, H., Kunisawa,
J., Yuki, Y. and Kiyono, H. 2004. Intestinal villous M cells: an antigen entry site in the mucosal epithelium. Proc. Natl. Acad. Sci. U. S. A. 101: 6110-6115.

21. Jani, P. U., Nomura, T., Yamashita, F., Takakura, Y., Florence, A. T. and Hashida, M. 1996. Biliary excretion of polystyrene microspheres with covalently linked FITC fluorescence after oral and parenteral administration to male Wistar rats. J. Drug Target. 4: 87-93.

22. Jepson, M. A., Simmons, N. L., Hirst, G. L. and Hirst, B. H. 1993. Identification of $M$ cells and their distribution in rabbit intestinal Peyer's patches and appendix. Cell Tissue Res. 273: 127-136.

23. Kitagawa, H., Hosokawa, M., Takeuchi, T., Yokoyama, T., Imagawa, T. and Uehara, M. 2003. The cellular differentiation of $\mathrm{M}$ cells from crypt undifferentiated epithelial cells into microvillous epithelial cells in follicle-associated epithelia of chicken cecal tonsils. J. Vet. Med. Sci. 65: 171-178.

24. Kitagawa, H., Yoshizawa, Y., Yokoyama, T., Takeuchi, T., Talukder, M. J. R., Shimizu, H., Ando, K. and Harada, E. 2003. Persorption of bovine lactoferrin from the intestinal lumen into the systemic circulation via the portal vein and the mesenteric lymphatics in growing pigs. J. Vet. Med. Sci. 65: 567-572.

25. Kucharzik, T., Lügering, N., Rautenberg, K., Lügering, A., Schmidt, M. A., Stoll, R. and Domschke, W. 2000. Role of M cells in intestinal barrier function. Ann. New York Acad. Sci. 915: $171-183$.

26. Marchetti, M., Sirard, J. C., Sansonetti, P., Pringault, E. and Kernéis, S. 2004. Interaction of pathogenic bacteria with rabbit appendix M cells: bacterial motility is a key feature in vivo. Microbes. Infect. 6: 521-528.

27. McLean, E. and Ash, R. 1987. The time-course of appearance and net accumulation of horseradish peroxidase (HRP) presented orally to rainbow trout Salmo gairdneri (Richardson). Comp. Biochem. Physiol. A. 88: 507-510.

28. Morris, B. and Morris, R. 1974. The absorption of ${ }^{125}$ I-labelled immunoglobulin $\mathrm{G}$ by different regions of the gut in young rats. J. Physiol. 241: 761-770.

29. Morris, B. and Morris, R. 1976. The effect of corticosterone and cortisone on the uptake of polyvinyl pyrrolidone and the transmission of immunoglobulin $\mathrm{G}$ by the small intestine in young rats. J. Physiol. 254: 389-403.

30. Owen, R. L. and Jones, A. L. 1974. Epithelial cell specialization within human Peyer's patches: An ultrastructural study of intestinal lymphoid follicles. Gastroenterology 66: 189-203.

31. Pang, K. Y., Walker, W. A. and Bloch, K. J. 1981. Intestinal uptake of macromolecules. Differences in distribution and degradation of protein antigen in control and immunized rats. Gut 22: 1018-1024.

32. Rodewald, R. 1980. Distribution of immunoglobulin G receptors in the small intestine of the young rat. J. Cell Biol. 85: 18-32.

33. Ross, M. H., Reith, E. J. and Romrell, L. J. 1989. Histology: a Text and Atlas, 2nd ed., Williams and Wilkins, U. S. A.

34. Sanderson, I. R. and Walker, W. A. 1993. Uptake and transport of macromolecules by the intestine: Possible role in clinical disorders (an update). Gastroenterology 104: 622-639.

35. Savidge, T. C., Smith, M. W., James, P. S. and Aldred, P. 1991. Salmonella-induced M-cell formation in germ-free mouse Peyer's patch tissue. Am. J. Pathol. 139: 177-184.

36. Shibahara, T., Sato, N., Waguri, S., Iwanaga, T., Nakahara, A., Fukutomi, H. and Uchiyama, Y. 1995. The fate of effete epithelial cells at the villous tips of the human small intestine. 
Arch. Histol. Cytol. 58: 205-219.

37. Soji, T., Murata, Y., Ohira, A., Nishizono, H., Tanaka, M. and Herbert, D. C. 1992. Evidence that hepatocytes can phagocytize exogenous substances. Anat. Rec. 233: 543-546.

38. Takeuchi, T., Kitagawa, H. and Harada, E. 2004. Evidence of lactoferrin transportation into blood circulation from intestine via lymphatic pathway in adult rats. Exp. Physiol. 89: 263-270.

39. Volkheimer, G. 1974. Passage of particles through the wall of the gastrointestinal tract. Environ. Health Perspect. 9: 215225.

40. Volkheimer, G. 1977. Persorption of particles: Physiology and pharmacology. Adv. Pharmacol. Chemother. 14: 163-187.

41. Volkheimer, G. 1993. Persorption von mikropartikeln. Pathologe 14: 247-252.

42. Volkheimer, G. and Schulz, F. H. 1968. The phenomenon of persorption. Digestion 1: 213-218.

43. Volkheimer, G., Schulz, F. H., John, H., Meier zu Eisen, J. and
Niederkorn, K. 1969. Persorbed food particles in the blood of new-borns. Gynaecologia 168: 86-92.

44. Volkheimer, G., Schulz, F. H., Lindenau, A. and Beitz, U. 1969. Persorption of metallic iron particles. Gut 10: 32-33.

45. Warshaw, A. L., Walker, W. A. and Isselbacher, K. J. 1974. Protein uptake by the intestine: evidence for absorption of intact macromolecules. Gastroenterology 66: 987-992.

46. Williams, E. W. and Hemmings, W. A. 1978. Intestinal uptake and transport of proteins in the adult rat. Proc. R. Soc. Lond. B Biol. Sci. 203: 177-189.

47. Yuji, M., Tsubata, M., Chin, K., Onishi, S., Inamoto, T., Qi, W.-M., Warita, K., Yokoyama, T., Hoshi, N. and Kitagawa, H. 2006. Persorption of luminal antigenic molecule and its specific antibody via apoptotic epithelial cells of intestinal villi and Peyer's patches into peripheral blood in rats. J. Vet. Med. Sci. 68: 1297-1305. 